\title{
PENINGKATAN AKTIVITAS DAN HASIL BELAJAR SISWA DENGAN MODEL PEMBELAJARAN KOOPERATIF TIPE JIGSAW DI KELAS XI IPA-1 DI SMA NEGERI 3 BAGAN SINEMBAH
}

\author{
Kartini \\ Surel : halimunimed@gmail.com
}

\begin{abstract}
ABSTRAK
Tujuan penelitian ini adalah Untuk mengetahui peningkatan aktivitas dan hasil belajar siswa dalam pembelajaran kimia dengan penerapan model pembelajaran kooperatif tipe Jigsaw pada kelas XI IPA-1 di SMA Negeri 3 Bagan Sinembah. Temuan dari penelitian tindakan kelas ini adalah: (1) Kegiatan belajar mengajar dengan menggunakan model pembelajaran kooperatif tipe Jigsaw berlangsung dengan baik, hal ini dapat dilihat dari hasil belajar siswa pada siklus I diperoleh siswa yang tuntas sebesar $61,35 \%$ dan menigkat menjadi $88,46 \%$ pada siklus II; (2) Aktivitas siswa dalam proses belajar mengajar dengan menggunakan model pembelajaran kooperatif tipe Jigsaw juga berjalan dengan maksimal, hal ini dapat dilihat dari hasil observasi yang dilakukan diperoleh pada siklus II aktivitas siswa memperoleh nilah sebesar $60 \%$ dengan kategori "cukup aktif" dan meningkat menjadi $82,5 \%$ pada siklus II dengan kategori "Aktif".
\end{abstract}

Kata Kunci : Kooperatif, Jigsaw, Kimia, Laju Reaksi.

\section{PENDAHULUAN}

Dalam proses pembelajaran kimia di beberapa sekolah selama ini terlihat kurang menarik, sehingga siswa merasa jenuh dan kurang memilik minat pada pelajaran kimia, sehingga suasana kelas cenderung pasif, sedikit sekali siswa yang bertanya pada guru meskipun materi yang diajarkan belum dapat dipahami. Dalam pembelajaran seperti ini mereka akan merasa seolah-olah dipaksa untuk belajar sehingga jiwanya tertekan. Keadaan demikian menimbulkan kejengkelan, kebosanan, sikap masa bodoh sehingga perhatian, minat, dan motivasi siswa serta hasil belajar dalam pembelajaran kimia menjadi rendah. Hal ini akan berdampak terhadap ketidaktercapaian tujuan pembelajaran kimia. Hasil penelitian yang dilakukan Sunyono (2005) selama ini ternyata rendahnya hasil belajar siswa tersebut disebabkan pada umumnya siswa mengalami kesulitan dalam menyelesaikan permasalahan yang menyangkut reaksi kimia dan hitungan kimia, akibat rendahnya rasa ingin tahu untuk bertanya kepada guru dan kerjasama antarasiswa saling bertanya dan menjelaskan satu dengan yang lain. Di samping itu, guru kurang memberikan contohcontoh konkrit tentang reaksi-reaksi yang ada di lingkungan sekitar dan sering dijumpai siswa. Oleh sebab itu, diperlukan suatu usaha untuk mengoptimalkan pembelajaran kimia di kelas dengan menerapkan model dan metode yang tepat. 

Hasil refleksi diri yang dilakukan peneliti dan diskusi dengan teman sejawat yang diminta melakukan observasi didalam kelas ketika mengajar bidang studi Kimia kelas XI IPA-1 di SMA Negeri 3 Bagan Sinembah ditemukan beberapa hal yang selama ini dirasakan guru ketika mengajar diantaranya yaitu: (1) Siswa kurang aktif dalam proses pembelajaran kimia dimana siswa kurang rasa ingin tahu dan malu bertanya walupun hanya kepada temannya sendiri apalagi kepada guru. (2) Siswa memiliki kecenderungan untuk berkelompok-kelompok sendiri bisa dikatakan memiliki gang-gang tersendiri di dalam kelas tersebut, sehingga sulit dalam mebaur dan bergaul, siswa pemalu akan tetap pemalu karena bergaul dengan siswa yang memiliki karakter yang sama; (3) Siswa cenderung memiliki sifat individualisme, siswa yang lebih memahami pelajaran enggan untuk memberikan ilmu kimianya kepada siswa yang lain; (4) Siswa kurang terlibat langsung dalam proses pembelajaran kimia sehingga siswa kurang menguasai materi pelajaran kimia dan tidak mampu mengerjakan soal-soal kimia yang diberikan; (5) Hasil belajar kimia siswa kelas XI IPA-1 kurang baik. Hal ini dapat dilihat dari nilai ulangan siswa kelas XI IPA-1 yang menunjukan hanya 60,50 \% siswa yang mengalami ketuntasan belajar. Nilai KKM untuk siswa kelas XI adalah $\geq 75$ dan siswa yang mendapatkan nilai di bawah 75 dinyatakan belum tuntas. Sedangkan secara klasikal ketuntasan belajar dinyatakan telah tercapaai jika sekurang-kurangnya telah terdapat $85 \%$ siswa telah memenuhi kriteria tuntas belajar perorangan.

Permasalahan yang ditemukan diatas membuat peneliti yang selama ini mengajar dikelas tersebut berusaha melakukan perbaikan pembelajaran, salah satu usaha memperbaiki pembelajaran tersebut yaitu melakukan Penelitian Tindakan Kelas (PTK), dalam penelitian tindakan kelas ini guru berdiskusi dengan teman sejawat untuk memperoleh gambaran model pembelajaran yang perlu digunakan agar dapat mengatasi permasalahan tersebut di atas, agar siswa dapat belajar bersama dengan berbagai karakter dan kemampuan yang berbeda serta dapat meningkatkan keaktifan belajar dan hasil belajar siswa. Model pembelajaran yang meningkatkan keaktifan dan hasil belajar kimia adalah model pembelajaran kooperatif. Pembelajaran kooperatif adalah "konsep yang lebih luas meliputi semua kerja kelompok termasuk bentuk-bentuk yang lebih dipimpin oleh guru atau diarahkan oleh guru" Suprijono (2011).

Dari beberapa penelitian terdahulu, menyimpulkan bahwa "model pembelajaran kooperatif tipe Jigsaw dapat meningkatkan aktivitas siswa dalam proses pembelajara Di SMK Negeri Tengaran. (Rinawan, Soni dan Krismiyanti, 2014), penelitian serupa juga dilakukan oleh 
Prisma Aswira (2012) model pembelajaran kooperatif tipe Jigsaw dapat meningkatkan prestasi belajar siswa khususnya kelas $\mathrm{X}$ IPA-3 SMA Negeri 1 Padang pada mata pelajaran kimia. Temuan penelitian diatas sejalan dengan pendapat Trianto, 2010 pembelajaran menggunakan model pembelajaran kooperatif tipe Jigsaw melibatkan semua peserta didik yang ada di kelas. Tujuan metode ini adalah mengembangkan kerja tim, keterampilan belajar kooperatif dan penguasaan materi.

\section{METODE PENELITIAN}

Selama perbaikan pembelajaran dilaksanakan, penulis selaku peneliti yang membutuhkan teman sejawat untuk melakukan observer mengamati aktivitas siswa selama proses pembelajaran berlangsung dan mencatat hal-hal yang penting untuk perbaikan pembelajaran. Prosedur perbaikan pembelajaran meliputi kegiatan pelaksanaan penelitian tindakan kelas yang disusun oleh Kemmis dan Mc Targgat yang terdiri dari 4 tahap yaitu perencanaan tindakan observasi dan refleksi, serta pelaksanaan penelitian ini direncanakan 2 siklus

\section{HASIL PENELITIAN DAN PEMBAHASAN}

Hasil temuan penelitian tindakan kelas dengan menggunakan Model Pembelajaran Kooperatif Tipe Jigsaw di kelas XI IPA-1 SMA Negeri 3 Bagan Sinembah pada siklus I pada materi Laju Reaksi dengan nilai ketuntasan minimal (KKM) 75, setelah melaksanakan pembelajaran dan dilakukan proses penilaian diperoleh data hasil belajar siswa dapat dilihat pada grafik.1 dibawah ini.

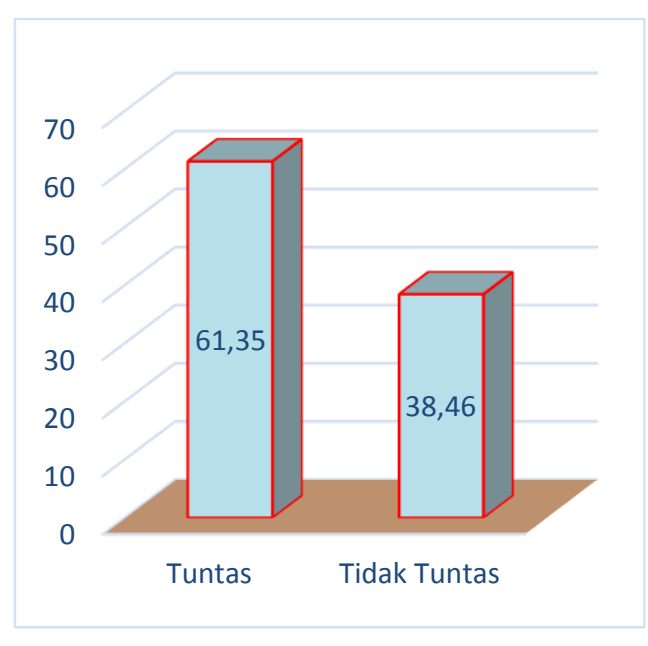

\section{Grafik Hasil Belajar Siklus I}

Dapat dilihat hasil belajar siswa pada siklus I pada mata pelajaran Kimia di SMA Negeri 3 Bagan Sinembah Kelas XI IPA-1 dengan menggunakan Model Pembelajaran Kooperatif Tipe Jigsaw. Dari 26 siswa kelas XI IPA-1 diperoleh 16 orang tuntas belajar atau sekitar $61,35 \%$ dan 10 orang atau sekitar 38,46\% tidak tuntas dan hasil observasi aktivitas siswa diatas dapat disimpulkan bahwa aktivitas siswa dalam kegiatan belajar mengajar dalam kategori "Cukup Aktif” walaupun pada aspek-aspek tertentu belum optimal diantaranya (1) Menganggapi/memberi pendapat;

(2) menjawab pertanyaan guru; (3) mengajukan pertanyaan; menguasai materi yang disampaikan dan (5) menyimpulkan hasil 
pembelajaran. Hal ini dikarenakan model pembelajaran koopertaif tipe Jigsaw masih baru bagi siswa sehingga belum terbiasa.

Setelah mengamati hasil belajar dan aktivitas siswa serta melakukan diskusi dengan teman sejawat dari hasil refleksi siklus I, maka siklus II dilanjutkan dengan perbaikan-perbaikan penyempurnaan bahan-bahan materi dan lama proses diskusi dan juga dipantau, menambah motivasi dalam proses belajar mengajar baik diawal pertemuan, kegiatan inti dan penutup didalam RPP yang diperbaharui dengan menggunakan Model Pembelajaran Kooperatif Tipe Jigsaw. Setelah melaksanakan pembelajaran dan dilakukan proses penilaian diperoleh data hasil belajar siswa dapat dilihat pada grafik 2 dibawah ini.

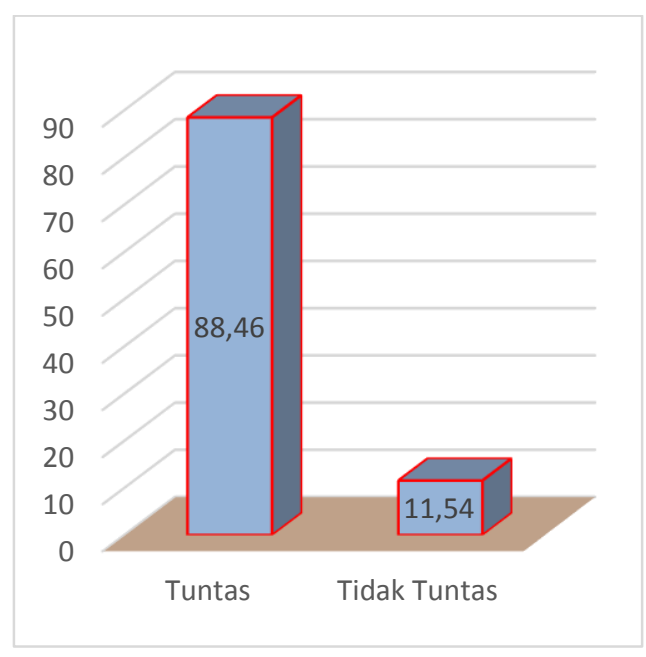

\section{Grafik Hasil Belajar Siklus II}

Dapat dilihat hasil belajar siswa pada siklus II pada mata pelajaran Kimia di SMA Negeri 3
Bagan Sinembah Kelas XI IPA-1 dengan menggunakan Model Pembelajaran Kooperatif Tipe Jigsaw. Dari 26 siswa kelas XI IPA-1 diperoleh 23 orang tuntas belajar atau sekitar $88,46 \%$ dan 3 orang atau sekitar 11,54\% tidak tuntas. Dari hasil belajar diatas dapat disimpulkan bawah pembelajaran Kimia pada siklus II telah berhasil karena telah mencapai ketuntasan belajar secara klasikal yang ditargetkan yaitu $85 \%$ tuntas dan hasil observasi aktivitas siswa diatas dapat disimpulkan bahwa aktivitas siswa pada siklus II meningkat sangat baik dalam kegiatan belajar mengajar dalam kategori "Aktif" walaupun pada aspek-aspek tertentu belum optimal diantaranya (1) Menganggapi/ memberi pendapat; peningkatan aktivitas siswa yang aktif ini menunjukkan bahwa penerapan model pembelajaran koopertaif tipe Jigsaw sudah terbiasa dilakukan siswa sehingga siswa nyaman melaksanakannya.

\section{Pembahasan}

Dari pertemuan yang diperoleh melalui kegiatan belajar yang dilaksanakan sebanyak 2 siklus, yang dilakukan dengan menggunakan tes dan observasi aktivitas siswa dalam kegiatan pembelajaran maka dapat dinyatakan bahwa model pembelajaran kooperatif tipe Jigsaw efektif dalam mata pelajara Kimia dengan materi laju reaksi hal ini terlihat dari: (1) Kegiatan belajar mengajar dengan menggunakan model pembelajaran 
kooperatif tipe Jigsaw berlangsung dengan baik, hal ini dapat dilihat dari hasil belajar siswa pada siklus I diperoleh siswa yang tuntas sebesar $61,35 \%$ dan menigkat menjadi $88,46 \%$ pada siklus II. Dan (2) Aktivitas siswa dalam proses belajar mengajar dengan menggunakan model pembelajaran kooperatif tipe Jigsaw juga berjalan dengan maksimal, hal ini dapat dilihat dari hasil observasi yang dilakukan diperoleh pada siklus II aktivitas siswa memperoleh nilah sebesar $60 \%$ dengan kategori "cukup aktif" dan meningkat menjadi $82,5 \%$ pada siklus II dengan kategori “Aktif”.

Efektifitas penggunaan model pembelajaran kooperatif tipe Jigsaw tersebut dimungkinkan karena pada kelompok ahli materi pembelajaran dibahas oleh semua anggota kelompok ahli secara mendalam sampai materi tersebut dipahami oleh semua anggota, kemudian semua anggota kelompok ahli kembali ke kelompok asal harus menyampaikan informasi yang diperoleh dari kelompok ahli ke kelompok asal, sehingga semua siswa ikut terlibat aktif dalam pembelajaran, dan siswa bisa saling tukar informasi tentang materi yang dipelajari dengan cara tutor sebaya.

\section{SIMPULAN}

Berdasarkan temuan hasil penelitian tentang "Peningkatan Aktivitas dan Hasil Belajar Siswa Dalam Pembelajaran Kimia Dengan Model Pembelajaran Kooperatif Tipe Jigsaw di Kelas XI IPA-1 di SMA
Negeri 3 Bagan Sinembah T.P 2015/2016", dapat ditarik kesimpulan sebagai berikut :

a. Kegiatan belajar mengajar dengan menggunakan model pembelajaran kooperatif tipe Jigsaw berlangsung dengan baik, hal ini dapat dilihat dari hasil belajar siswa pada siklus I diperoleh siswa yang tuntas sebesar $61,35 \%$ dan menigkat menjadi $88,46 \%$ pada siklus II.

b. Aktivitas siswa dalam proses belajar mengajar dengan menggunakan model pembelajaran kooperatif tipe Jigsaw juga berjalan dengan maksimal, hal ini dapat dilihat dari hasil observasi yang dilakukan diperoleh pada siklus II aktivitas siswa memperoleh nilah sebesar $60 \%$ dengan kategori “cukup aktif" dan meningkat menjadi $82,5 \%$ pada siklus II dengan kategori "Aktif".

\section{DAFTAR RUJUKAN}

Anita, lie. 2002. Cooperatif Learning (mempraktekkan kooperatif learning di ruang-ruang kelas. Jakarta: Gramedia

Djamarah, Saiful Bahri. dan Aswan Zain. 2002. Strategi Belajar Mengajar. Jakarta: Rineka Cipta.

Rusman. 2008. Model-Model Pembelajaran.Bandung: Mulia Mandiri Press

Rohani, Ahmad. 2004. Pengelolaan Pengajaran. Jakarta: Rineka Cipta 
SEJ VOLUME 7 NO. 2 JUNI 2017

Sardiman. 2014. Interaksi dan Motivasi Belajar Mengajar. Jakarta: Rajawali.

Slavin, Robert, E. 2009. Cooperative Learning (Teori, Riset,
Praktik). Bandung: Mulia Mandiri Press.

Upriono, Agus. 2009. Cooperatif Learning. Yogyakarta: Pustaka Pelajar. 